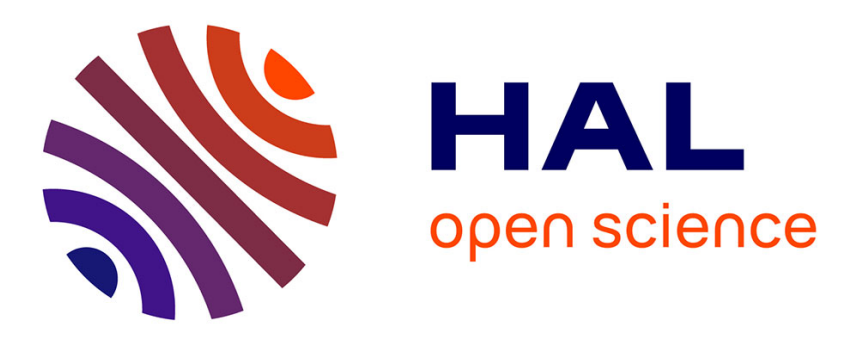

\title{
Positive effect of climate change on cotton in 2050 by CO2 enrichment and conservation agriculture in Cameroon
}

\author{
Edward Gérardeaux, Benjamin Sultan, Oumarou Palaï, Camille Guiziou, \\ Pascal Oettli, Krishna Naudin
}

\section{To cite this version:}

Edward Gérardeaux, Benjamin Sultan, Oumarou Palaï, Camille Guiziou, Pascal Oettli, et al.. Positive effect of climate change on cotton in 2050 by CO2 enrichment and conservation agriculture in Cameroon. Agronomy for Sustainable Development, 2013, 33 (3), pp.485-495. 10.1007/s13593-0120119-4 . hal-01201362

\section{HAL Id: hal-01201362 \\ https://hal.science/hal-01201362}

Submitted on 17 Sep 2015

HAL is a multi-disciplinary open access archive for the deposit and dissemination of scientific research documents, whether they are published or not. The documents may come from teaching and research institutions in France or abroad, or from public or private research centers.
L'archive ouverte pluridisciplinaire HAL, est destinée au dépôt et à la diffusion de documents scientifiques de niveau recherche, publiés ou non, émanant des établissements d'enseignement et de recherche français ou étrangers, des laboratoires publics ou privés. 


\title{
Positive effect of climate change on cotton in 2050 by $\mathrm{CO}_{2}$ enrichment and conservation agriculture in Cameroon
}

\author{
Edward Gérardeaux • Benjamin Sultan • \\ Oumarou Palaï • Camille Guiziou • Pascal Oettli • \\ Krishna Naudin
}

Accepted: 23 October 2012 / Published online: 15 November 2012

(C) INRA and Springer-Verlag France 2012

\begin{abstract}
This article predicts an unexpected positive effect of climate change on cotton production in Cameroon. Global warming could threaten cotton production in Africa due to increasing temperature and $\mathrm{CO}_{2}$, and rainfall uncertainties. This situation is worsened by the fact that most African farmers grow cotton as their cash crop and have few or no possible alternatives. Assessing the impact of climate change on cotton production is therefore critical. Here, we used CROPGRO, a process-based crop model that can simulate the main features of cotton growth and management. We applied this model to two regions in North Cameroon and a set of six regional climate projections combining general climate models and regional climate models from the ENSEMBLES project. The model was calibrated and validated with a data set of observations made in farmer fields from 2001 to 2005 and at an experimental station in 2010. Our results show unexpectedly that climate change from 2005 to 2050 in North Cameroon will have a positive effect on cotton yields with an increase of $1.3 \mathrm{~kg} \mathrm{ha}^{-1}$ year $^{-1}$ in yield, especially if conservation agriculture systems are adopted. The predicted increase of $0.05{ }^{\circ} \mathrm{C}_{\text {year }}{ }^{-1}$ in temperature will shorten crop cycles by 0.1 day year ${ }^{-1}$ with no negative effect on yields. Moreover, the fertilizing effect of $\mathrm{CO}_{2}$ enrichment will
\end{abstract}

E. Gérardeaux $(\bowtie) \cdot$ C. Guiziou $\cdot$ K. Naudin

CIRAD,

Avenue Agropolis-TA B-102/02,

34398 Montpellier Cedex 5, France

e-mail: gerardeaux@cirad.fr

B. Sultan · P. Oettli

IRD,

Université Pierre et Marie Curie Boite 100, 4 Place Jussieu,

75252 Cedex 5, Paris

O. Palaï

IRAD,

Centre Régional de Recherche Agricole de Maroua,

BP 33 Maroua, Cameroun increase yields by approximately $30 \mathrm{~kg} \mathrm{ha}^{-1}$. The rainfall pattern is likely to change, but the six regional models used to generate future weather patterns did not predict a decrease in rainfall. One model even forecast an increase in rainfall amounts. According to our findings, climate changes in North Cameroon can be anticipated by tailoring alternative cropping systems and adaptation techniques to cope with climate change.

Keywords Cotton (Gossypium hirsutum L.) · Climate change $\cdot$ North Cameroon $\cdot$ Cropping systems $\cdot$ Crop modeling

\section{Introduction}

The Fourth Assessment Report of the Intergovernmental Panel on Climate Change (IPCC 2007) has, with greater confidence than previous reports, warned the international community that the increase in greenhouse gas emissions will result in global climate change. Associated with the expected worldwide rise in temperature, precipitation patterns and quantities will likely change, evaporative demand will increase. These changes may have disastrous effects on human activities in highly vulnerable regions like tropical Africa where rural populations depend heavily on rainfed agriculture and where widespread poverty limits their capacity to cope with climate variability and change. For West Africa in particular, a meta-analysis of the results of 16 studies (Roudier et al. 2011) shows that in most cases, the effect of climate change on crop yield is expected to be negative. However the meta-analysis also revealed a wide range of projected crop yields ranging from -50 to $+90 \%$, thus justifying a low level of confidence in future yield projections. The wide range of crop yield projections reflect different conditions in the locations where the impact studies were conducted, and relied on different climate 
projections, crops and crop models, and downscaling techniques. Since increased $\mathrm{CO}_{2}$ does not only drive climate change but can also have beneficial physiological effects on crops by stimulating photosynthesis and reducing drought stress (Tubiello et al. 2007), uncertainty is particularly high in the case of $\mathrm{C}_{3}$ crops (e.g. soybean, groundnut, and cotton), for which the $\mathrm{CO}_{2}$ fertilization effect could sometimes compensate for yield loss caused by climatic parameters, and sometimes even reverse it (Roudier et al. 2011). In the case of $\mathrm{C}_{3}$ crops, the balance between detrimental and positive effects of climate change therefore needs to be addressed with caution.

Among $\mathrm{C}_{3}$ crops, cotton (Gossypium hirsutum L.) is particularly important in West and Central Africa since, when considered as a regional entity, the sub-continent is the world's third largest exporter after the USA and Central Asia. Cotton production represents an important source of income for African countries, especially North Cameroon, where it is the main cash crop, covering $30 \%$ of the agricultural landscape (Mbétid-Bessane et al. 2006) as well as the main source of income (monetary income for growers in particular). Recent studies demonstrated that like in Mali, climate is an important driver of crop productivity in North Cameroon (Blanc et al. 2008; Sultan et al. 2010). These authors pointed to the role of the onset and the length of the rainy season in crop yield variability in the region. However, these studies were based on data collected during the past 50 years and did not provide any indications on how cotton yields will evolve under climate change scenarios. Furthermore, they relied only on empirical relationships between crop yield and climate, neglecting a lot of important processes for cotton growth such as soil fertility and management as well as the effect of $\mathrm{CO}_{2}$ enrichment that could play an important role in future yields.

The objectives of the present study were to assess the impact of climate change scenarios on cotton production in North Cameroon under different cropping systems and to examine the uncertainty introduced by climate projections in impact assessment. To this end, we used a process-based crop model capable of realistically simulating the main features of cotton growth and management in the region. Several models are available for simulating cotton growth, including GOSSYM, APSIM, and CROPGRO. Among these models, CROPGRO-cotton appeared to us to be the most appropriate as it combines an acceptable set of physiological bases, has the ability to simulate rotations and mulch effects, and has already been successfully used by Tingem et al. (2009) to assess the impacts of climate change on bambara nut, groundnut, maize, sorghum, and soybean in Cameroon. The Decision Support System for Agrotechnology Transfer (DSSAT) suite of models (Jones et al. 2003) including CROPGRO was thus selected for this study. Particular importance was given to the design of the protocol used to simulate the different cropping systems used in the region. After decades of increasing seed cotton yields since the introduction of cotton in the 1950s, yields obtained with conventional cotton cropping systems have been falling for more than a decade now (Naudin et al. 2010). To increase the sustainability of crop yields, for the last 10 years, Cameroon research and extension services have been implementing soil restoration measures through conservation agriculture with no tillage, mulch, and the use of cover crops in rotation. At the same time, the farmers themselves have developed a no-tillage system with direct seeding on bare soil to reduce weed infestation and to allow them to sow crops early in the season. While these cropping systems led to some improvements in yield in both controlled conditions and in farmer fields (Naudin et al. 2010), there are still some major obstacles to a large-scale extension of the systems. The first is that during the first 2 years of a conservation agriculture system, crop performance can be mixed. Crops under conservation agriculture often experience nitrogen stress at the beginning of the season and weed control is not easy. Second, the production and maintenance of the plant biomass is complicated. Farmers make trade-offs between feeding animals and the need for a soil cover. Moreover, the fields need to be protected from the burning of savannah. The yield increase observed with the conservation agriculture systems in North Cameroon was achieved mainly through better use of water resources by limiting soil runoff and evaporation (Soutou et al. 2007). One benefit of no-tillage systems is that crops are sown earlier than in conventional systems. The seeds can be sown when the first rain falls, even in a dry soil, whereas farmers who use a cattle drawn plow have to wait for the draft animal to be available and for the soil to have the appropriate moisture content (20-mm rainfall). Naudin et al. (2010) also showed that with conservation agriculture, increased water availability at the end of the rainy season for the crop delayed the end of flowering. Such differences may be of particular interest in the context of global climate change when evaporative demand increases and rainfall decreases during crucial growth periods for the crops. Being able to identify the most robust system to withstand climate change among the three cropping systems described is crucial for formulating adaptation strategies in the region.

The methods and the details of these simulations are presented in the following section. Simulation results are presented in Section 3, and Section 4 presents the conclusion.

\section{Materials and methods}

\subsection{Study design}

The study was conducted over a period of 6 years (20012005 and 2010). The data set used for the study came from 
two separate experiments. Experiment 1 was conducted in farmer fields from 2001 to 2005 in the North and Far North provinces of Cameroon in an area located between $11^{\circ} 02^{\prime} \mathrm{N}$ and $10^{\circ} 58^{\prime} \mathrm{N}$. Experiment 2 was conducted in experimental fields in the same provinces in 2010. The Far North province is characterized by a Sahelo-Sudanian climate with a rainy season from June to September. The North Province has an extended rainy season from May to October. The rainfall amount measured from 1979 to 2010 at the weather station in the Far North Province averaged $798 \mathrm{~mm}$ with $163 \mathrm{~mm}$ of standard deviation. In the North Province, it averaged $806 \mathrm{~mm}$ with $271 \mathrm{~mm}$ of standard deviation. Both provinces have a wide range of soil types that mainly vary according to their position on the slopes. Soil texture ranges from fine clay to sandy. See Naudin et al. (2010) for more details concerning the farmer fields.

\subsubsection{Experiment 1 in farmer fields}

Three cereal/cotton rotation systems are used in North Cameroon: a conventional cropping system with tillage and two "improved" cropping systems: one using direct mulch, and the other a no-tillage system. Farmer fields were approximately $2,500 \mathrm{~m}^{2}$ in size. The fields (Fig. 1) were divided into two or three plots and one system was used in each plot (conservation agriculture, no tillage, or tillage). In the conservation agriculture system, cotton was sown in mulch left over from the previous crop, maize, or sorghum, either grown as a sole crop or in association with a cover crop of either brachiaria (Brachiaria ruziziensis), crotalaria (Crotalaria retusa L.), or mucuna (Mucuna pruriens Bak). On tillage plots, the soil was plowed to a depth of $15 \mathrm{~cm}$ with an ox-drawn plow. Cotton was sown with a hoe to cause minimum disturbance of the soil surface. The cotton cultivars used were those available to local farmers (IRMA 1239 and IRMA BLT-PF). Weeds were controlled by hoeing and herbicides were applied. Pests were controlled according the conventional plant protection program.

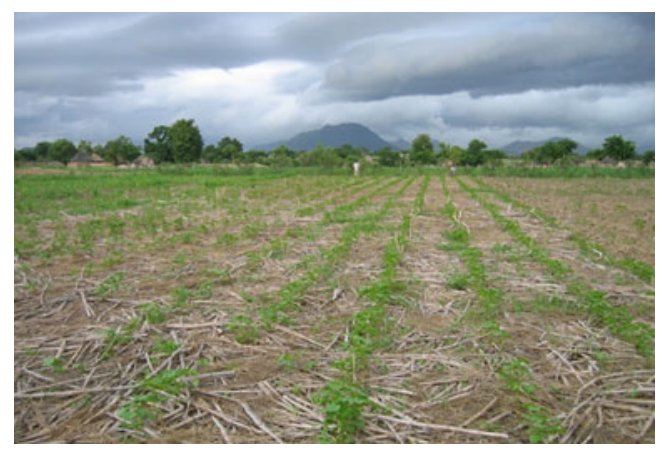

Fig. 1 Photograph of a farmer cotton field, North Cameroon, 2004. In the center, note the conservation agriculture plots and on the right part note the tilled plot with smaller plants
The farmers were free to use as much fertilizer as they wanted but an extra dose of $22 \mathrm{~kg} \mathrm{ha}^{-1}$ of nitrogen was applied in conservation agriculture plots. In this section, we give average nitrogen fertilization values. Tillage plots received $29 \mathrm{~kg} \mathrm{ha}^{-1}$ of nitrogen fertilizer split into two applications, one at planting and one 50 days after sowing. The conservation agriculture system received $44 \mathrm{~kg} \mathrm{ha}^{-1}$ of nitrogen fertilizer split into two applications, one at planting and one 50 days after sowing. The no-tillage system received $22 \mathrm{~kg} \mathrm{ha}^{-1}$ of nitrogen fertilizer split into two applications, one at planting and one 50 days after sowing. The same form of nitrogen $\left(\mathrm{NH}_{4} \mathrm{NO}_{3}\right)$ was used in all the systems.

Technical management of the cotton crop was assessed through interviews with the farmers two or three times a month. Cotton yield was measured by harvesting and weighing cotton seeds in every fifth row. The length and the width of each harvested row were characterized to enable extrapolation on an area basis. Daily rainfall was recorded in each village with a rain gauge. Soil texture was determined using the VS-FAST method (McGarry 2006) on soil samples taken from the $0-20$ - and $20-40-\mathrm{cm}$ soil layers. Soil depth was estimated by manual digging to a depth of $1 \mathrm{~m}$. The beginning and end of flowering were estimated visually and recorded when flowering had started and ended in half of the plants.

A subset of eight plots in different locations in the Far North Province was monitored during the 2004 cropping season to validate the water budget: rainfall, soil water content, and runoff were measured for the tillage and conservation agriculture systems. Runoff was measured directly with collectors and soil humidity by weighing the soil at different dates. The beginning and end of flowering were estimated visually by technicians and recorded when flowering had started and ended in half of the plants.

\subsubsection{Experiment 2 in research stations}

Two experiments were conducted, one in Sanguere research station near Garoua and one in Kodeck research station near Maroua. The 2010 experiment compared two local cultivars (L484 and L457) and two sowing dates (recommended and late). These cultivars are successors of IRMA A1239 and IRMA BLT-PF; they are genetically close to their predecessors but with improved fiber quality (strength, length, maturity, and micronaire). In addition to the same observations on yield and phenology as those conduced in experiment 1 , leaf area index, dry matter content, number of shells and seeds, threshing percentage, and oil and protein contents were recorded.

\subsection{Climatic data}

Two synoptic weather stations located in Maroua and Garoua run by the AGRHYMET Regional Center were used 
as local ground truth. These stations record rainfall and other meteorological parameters at a height of $2 \mathrm{~m}$ from the ground including solar radiation, insolation, surface wind speed, humidity, and temperature. Daily data are available from 1950 to 2010. The weather data used for our simulations were rainfall (millimeters per day), minimum and maximum air temperature (degrees Celsius), insolation duration (hours per day), dew point temperature, wind speed, and potential evaporation (millimeters per day). The data were recorded at three synoptic weather stations located in Garoua, Maroua, and Kaélé. The experimental plots were located at a distance of nearly $5,000 \mathrm{~m}$ from the weather station. Many years were missing in the Kaélé data set which was consequently only used to calibrate and validate CROPGRO, while the data from Garoua and Maroua were used to generate climate scenarios.

\subsection{ENSEMBLES regional climate changes scenarios}

A coherent multi-model experiment has been underway since the beginning of the ENSEMBLES project (20042009) (van der Linden and Mitchell 2009). A set of ten regional configurations with eight regional models are available for West and Central Africa using two global climate models as lateral boundary conditions for the 2010-2050 period under scenario A1B (Nakicenovic et al. 2000). The use of several global and regional climate models enables the uncertainty in both large-scale and regional-scale climate projections to be covered. For our purpose, we used six regional configurations:

- HIRHAM model: Danmarks Meteorologiske Institut (DMI),

- CLM model: Gesellschaft fur Kernenergieverwertung in Schiffbau und Schiffahrt GKSS-Forschungszentrum (GKSS),

- RACMO model: Koninklijk Nederlands Meteorologisch Instituut (KNMI),

- HIRHAM model: Meteorologisk institutt (METNO),

- RCA model: Sveriges Meteorologiska och Hydrologiska Institut (SMHI),

- PROMES model: Universidad de Castilla-La Mancha (UCLM).

The DMI, GKSS, and KNMI regional configurations were forced by ECHAM5 A1B climate change scenario while METNO, UCLM, and SMHI were forced by HadCM3. Regional climate outputs are freely available at a daily time scale at a $50-\mathrm{km}$ resolution for the AMMA region. All variables needed to force the crop model were selected at the daily time step and bilinearly interpolated to each of the two synoptic stations in North Cameroon. Climate models have serious regional biases for different climate variables and a bias correction is thus required before using climate projections for crop modeling purposes. In order to correct the statistical distributions of the regional climate model simulations and to make them as close as possible to those of the observations, the transformation of cumulative distribution function method (Michelangeli et al. 2009) was applied. This method aims to correct the cumulative distribution function of a variable (temperature or precipitation, etc.) given at a relatively low resolution from a regional climate model simulation into the CDF of the equivalent variable at a much smaller scale. In the present study, the required cumulative distribution functions were non-parametrically estimated, but with a monthly discrimination. From May to November, a monthly correction was applied to each variable, by calibrating a monthly cumulative distribution function for the period 1979-2004. The cumulative distribution function was then applied to each regional climate output for the period 2005-2050. Corrected downscaled outputs were then used to drive the crop model described above.

\subsection{Cotton growth simulations}

\subsubsection{The DSSAT crop model}

The DSSAT 4.5.0.0 cropping system model (DSSAT-CSM) beta version 2011 (Jones et al. 2003) was used for this study. DSSAT-CSM uses a set of codes to simulate soil nitrogen, water, and carbon dynamics, while crop growth and development is simulated by plant models (Crop Environment Resource Synthesis (CERES), generic CROP GROwth model(CROPGRO), Simulation of Underground Bulking Storage Organs (SUBSTOR), etc.). Soil inputs included albedo, photosynthesis factor, $\mathrm{pH}$, drainage, and runoff coefficients set at $0.14,1,6.0,0.25$, and 81 , respectively. The model also required the soil properties of different layers. The soil characteristics used were water holding capacity, saturated hydraulic conductivity, bulk density, nitrogen content, and organic carbon. After soil analysis, the surface layers were set respectively at $0.073 \mathrm{~cm}^{-3} \mathrm{~cm}^{3}, 1.59,1.48 \mathrm{~g} \mathrm{~cm}^{-3}, 0.05 \mathrm{~g} \mathrm{~g}^{-1}, 0.7 \mathrm{~g} \mathrm{~g}^{-1}$ in Garoua and $0.09 \mathrm{~cm}^{-3} \mathrm{~cm}^{3}, 2.59,1.41 \mathrm{~g} \mathrm{~cm}^{-3}, 0.04 \mathrm{~g} \mathrm{~g}^{-1}$, $0.7 \mathrm{~g} \mathrm{~g}^{-1}$ in Maroua. The conservation agriculture system was parameterized with no tillage, a mulch cover of $4 \mathrm{~T} \mathrm{ha}^{-1}$ of residues containing $1 \% \mathrm{~N}$. The preceding crop (maize, sorghum) residue was set at $1 \mathrm{~T} \mathrm{ha}^{-1}$ of roots and $2 \mathrm{~T} \mathrm{ha}^{-1}$ of unincorporated stems containing $0.5 \% \mathrm{~N}$. The following simulations options were chosen: (1) Suleiman Ritchie for soil water balance, (2) Priestley-Taylor/Ritchie for evapotranspiration, (3) CROPGRO was run in the experimental mode, and (4) CERES-Godwin for soil organic matter. Ideally, CENTURY would be the best sub-model to use for organic carbon dynamics but it was developed with data from temperate regions, and the proportion between soil organic compartments and their response to $T^{\circ}$ are not adapted to tropical conditions. As we had no observed data to use for its 
parameterization, we chose to use the default CERES-Godwin sub-model. CROPGRO was run in experimental mode.

The original genetic parameters required for CROPGROcotton are: time between plant emergence and flower appearance, time between first flower and first pod, time between first flower and first seed, time between first seed and physiological maturity, time between first flower and end of leaf expansion, relative maximum leaf photosynthesis rate at $30^{\circ} \mathrm{C}, 350 \mathrm{vpm} \mathrm{CO}_{2}$, and high light intensity, specific leaf area of cultivar (centimeter squared per gram), maximum size of full leaf (centimeter squared), maximum fraction of daily growth that is partitioned to seed + shell, maximum weight per seed (gram), seed filling duration for pod cohorts under standard growth conditions, number of seeds per pod under standard growing conditions, time required for cultivar to reach final pod load under optimal conditions, maximum ratio of seed/ (seed + shell), fraction of protein in seeds, fraction of oil in seeds. There values were set respectively at 39,12 , $15.0,40,75,1.05,170,300,0.72,0.18,34.0,27,14$, $70,0.15$, and 0.12 , according to the calibration of the American cultivar Deltapine 458.

\subsubsection{Calibration of the model}

The dataset for calibration came from the experiments conducted in 2001, 2002, 2004, and 2010. Part of the data collected in 2005 and 2010 was kept for validation of the crop simulation (see Section 3.1).

In our calibration procedure, we varied the parameter values to minimize the RMSE. Generalized likelihood uncertainty analysis (GLUE), a Bayesian method, allows information from different types of observations to be combined to estimate probability distributions of parameter values and model predictions (He et al. 2010). GLUE software was used to calibrate the genetic coefficients to fit the phenology variables through anthesis and maturity dates and growth variables through the maximum leaf area index, crop weight, yield, grain number, and dry weight at maturity. Approximately 8,000 runs were made with GLUE. Leaf area index and the dry weight of aerial parts were only recorded in 2010. After the automatic procedure, we improved calibration using a manual and iterative approach. The genetic parameters were refined and adjusted to fit time series observation data (leaf area index and dry weight of aerial parts).

Fiber and seed analysis of the cotton seed of the cultivars IRMA 1239, IRMA BLT-PF, L457, and L484 were conducted by the genetic research team when these cultivars were first experimented. We used the following data: seed index, cotton ginning percentage, seed oil, and protein content. These data were transformed into the corresponding genetic parameters for the DSSAT cultivar file. The threshing percentage was measured on the recent cultivars IRMA
457 and IRMA 484 experimented in 2010 and 2011. We used the same values for all the cultivars.

\subsubsection{Calibration of CROPGRO-cotton cultivars}

The calibration of cotton cultivars produced new genetic parameters (data not shown). The time between emergence and flowering and the seed filling duration were slightly shorter in the final cultivars. Some physiological parameters also differed after the calibration process. The specific leaf area increased and the maximum leaf size was smaller. Seeds underwent other changes: the number of seeds per boll was lower, the time for grain filling was shorter and the oil and protein fractions were larger.

\subsubsection{Validation of CROPGRO-cotton under different cropping systems}

The validation process was undertaken in two steps. First, we did a classical comparison of observed and simulated phenology (flowering and maturity date) and cottonseed yields using the whole set of plots. Second, we compared the yields, the length of flowering, and soil water variables for each cropping system on a subset of data based on field observations of water rainfall, runoff, soil moisture, and flowering duration. The comparison of observed and simulated duration of flowering was a tradeoff as the model does not simulate the end of flowering but the addition of pods. The end of flowering was calculated as the days when plants stopped adding pods (the top of the curve of pod number versus time in plantgro.out file).

\section{Results and discussion}

\subsection{Validation of CROGRO-cotton cultivars and simulations}

CROPGRO accurately simulated the average onset of flowering and maturity in 2001, 2002, 2004, and 2010 (Fig. 2a, b). However, it did not simulate the individual variability of flowering and maturity dates observed. This bias resulted from: (1) the phenology routine in CROPGRO, which accounts for average temperature but does not adequately account for crop nutritional status and other external factors, and (2) the fact that we used the same climatic data in a given year for a set of different fields without considering their microclimates. Despite the discrepancy between the observed and simulated onset of phenological events, our data suggest that CROPGRO gives a satisfactory average result.

The changes in the cultivar parameters after the calibration process is interesting to interpret as modern African cultivars are the result of crosses between American and African native genotypes and selection among descendants. These changes 
Fig. 2 Observed and simulated onset of anthesis and maturity of cotton crops in North

Cameroon, calibration (a) and validation (b) data sets. Observed and simulated cotton seed yield in 2001 (white square), 2002 (white triangle), 2004 ( $x$ sign), 2005 (triangle), and 2010 (plus sign), tillage system (red), conservation agriculture (blue), no-tillage (yellow) calibration (c), and validation (d) data sets. Note the wide range of observed yields. Regression equation were c $\left(y=0.9028 x, R^{2}=0.78\right)$, d $\left(y=0.7866 x, R^{2}=0.48\right)$

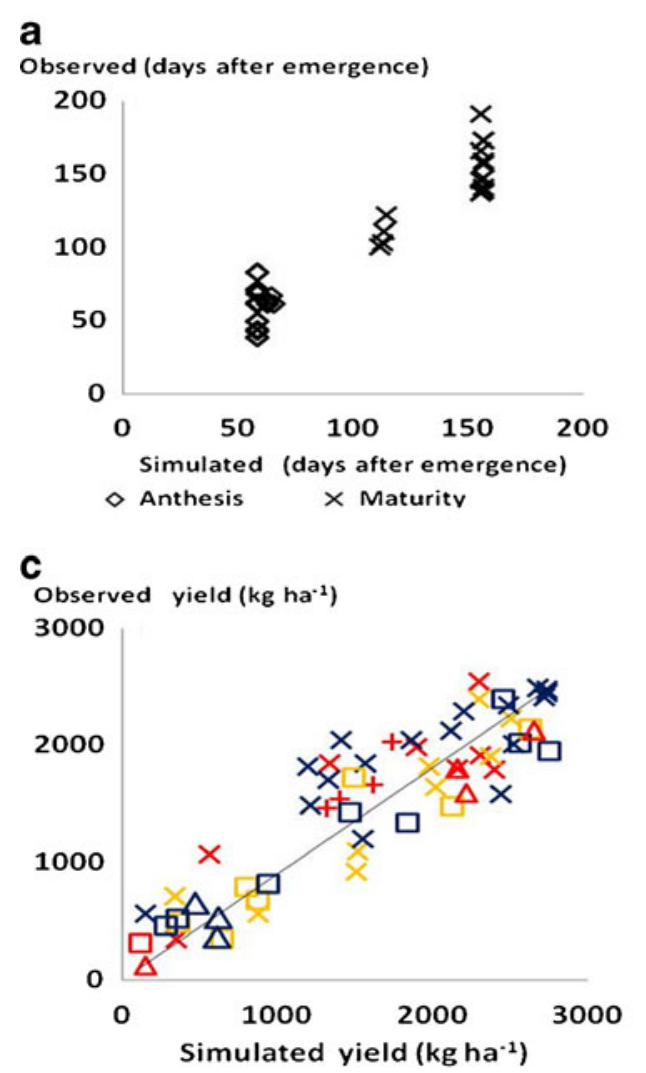

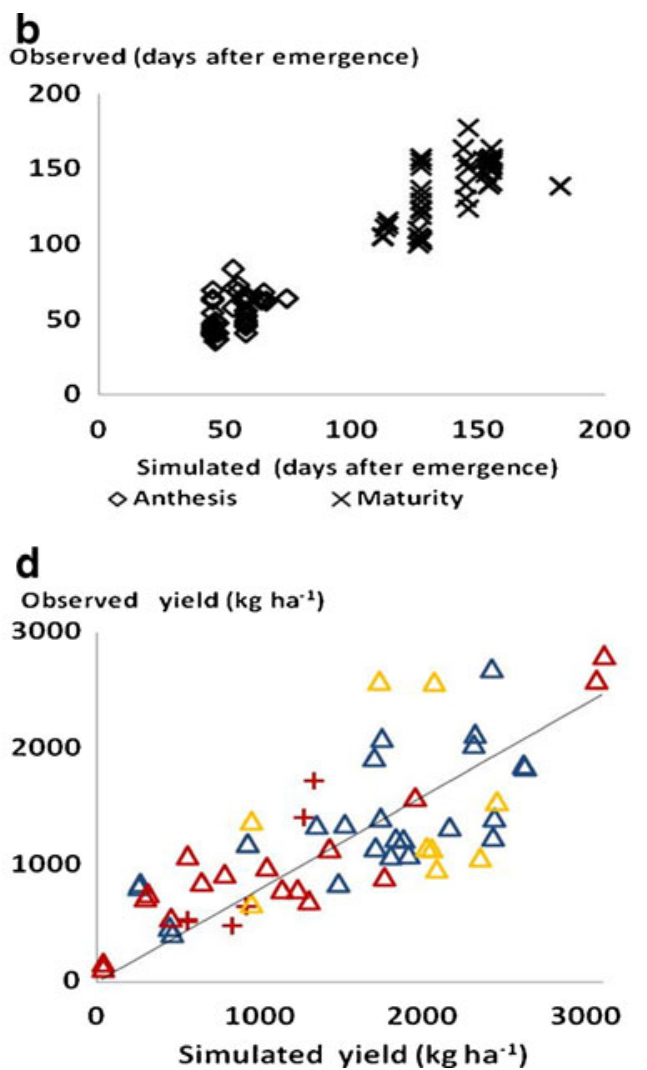

reflect differences in crop phenology, and in growth and yield components. The most noticeable changes are in leaf and seed parameters. African cultivars have smaller and thinner leaves. African cultivars produce fewer seeds per boll in a shorter time and with different oil and protein contents. Our post calibration values for oil and protein contents were closer to real values (Turner et al. 1975) than to initial values.

In addition to validation of crop phenology, the average availability of soil water at $0-30$ and 30-60 days after planting and the water budget components are listed in Table 1 both for observations and simulations. Observed and simulated values matched well, with, in particular, good distribution of the water budget in the model compared to ground data. Conservation agriculture enabled an improvement in water availability owing to a decrease in runoff and probably to a decrease in evaporation. Steiner (1989) in a temperate climate, as well as Scopel et al. (2004) in tropical and semi arid climates and many other authors, demonstrated that a key principle of conservation agriculture cropping systems is allowing crop residues to remain on the soil surface to protect soil water from evaporation. In the field experiments, the better availability of water for the crop under conservation agriculture led to a delay in the end of flowering (Naudin et al. 2010). Under conservation agriculture, the observed flowering period of the cotton crop was 9 to 14 days longer than crops grown under other cropping systems (tillage or no tillage) as shown in Table 1. The simulations also revealed differences in flowering duration between conservation agriculture and other systems, but to a lesser extent (respectively 8 and 4 days for tillage and no tillage compared to conservation agriculture). Growth variables and yield components were also recorded for calibration purposes. In 2010, leaf area index and top dry matter were only measured in four treatments. With an average maximum leaf area index of 3 for an observed value of 4.5; CROPGRO underestimated the maximum leaf area index produced by the crop. Despite this underestimation, the dry matter produced was well simulated with a regression coefficient $\left(R^{2}\right)$ of 0.93 . The $R^{2}$ between observed and simulated boll number and seed weight was respectively 0.58 and 0.11 . The first result can be considered to be correct for validation with a set of poorly estimated data on soil chemical and physical properties, climate data recorded at a distance of nearly $30 \mathrm{~km}$ from the field, and with the assumption of perfect weed and pest control. On the other hand, the simulation of seed weight was not accurate. Despite poor simulation of seed weight, the satisfactory simulation of water availability, crop dry matter, flowering period, and seed number led to a rather good simulation of cotton seed yields.

Observed yields ranged from 130 to $2,800 \mathrm{~kg} \mathrm{ha}^{-1}$ (Fig. 2c, d). This wide range of observed yields was caused by climate variability combined with a wide range of cultural practices and soil conditions. Sowing dates ranged 
Table 1 Cumulative runoff (millimeter) from planting to harvest, soil water contents (cubic centimeter per cubic centimeter) at 0-30 and 30-60 days after planting, cottonseed yield (kilogram per hectare) and flowering duration (day)

\begin{tabular}{|c|c|c|c|c|c|c|c|c|}
\hline \multirow[b]{2}{*}{ Name of variable } & \multicolumn{3}{|l|}{ Observed } & & \multicolumn{3}{|l|}{ Simulated } & \\
\hline & $\begin{array}{l}\text { Conservation } \\
\text { agriculture }\end{array}$ & Tillage & No tillage & & $\begin{array}{l}\text { Conservation } \\
\text { agriculture }\end{array}$ & Tillage & No tillage & \\
\hline Cumulative runoff & $60 \mathrm{~B}$ & $122 \mathrm{~A}$ & - & $*$ & $35 \mathrm{~B}$ & $85 \mathrm{~A}$ & - & * \\
\hline Soil water content at $0-30$ days after planting & $21.0 \mathrm{~A}$ & $16.5 \mathrm{~B}$ & - & $*$ & 19.2 & 15.4 & - & * \\
\hline Soil water content at $30-60$ days after planting & 19.8 & 18.9 & - & NS & 18.3 & 16.5 & - & * \\
\hline Cottonseed yields & $1,952 \mathrm{~A}$ & $1,861 \mathrm{AB}$ & $1,428 \mathrm{~B}$ & * & 1,790 & 1,771 & 1,520 & NS \\
\hline Flowering duration & 104 & 90 & 95 & $*$ & 98 & 94 & 90 & NS \\
\hline
\end{tabular}

Observed from historical data in 2004 and simulated means for conservation agriculture, tillage and no-tillage treatments, and statistical analysis for eight paired comparisons. Observed flowering duration was calculated from flowering to end of flowering and simulated fruiting period from flowering to end of boll addition

Values followed by different letters (A and B) in the same line are statistically different according to Newman-Keuls test

$N S$ not significant, “-” data not available

${ }^{*} p<0.05$, by ANOVA

from early May to mid July, flowering duration from 25 to 140 days. Crop density ranged from two to eight plants square meter. Nitrogen fertilization ranged from 0 to $150 \mathrm{~kg} \mathrm{ha}^{-1}$, soil types ranged from shallow sand to deep heavy clays. The yields for different tillage systems were correctly simulated, as shown in Table 1. Conservation agriculture produced more cottonseed than tillage and no-tillage systems. These gains could be attributed to more than the mulch, as respectively 15 and $22 \mathrm{~kg} \mathrm{ha}^{-1}$ more fertilizer was used under the conservation agriculture systems. However, the model simulates a longer period without water stress (data not shown) and a longer flowering duration as a result of a better water balance, which is likely to produce more cottonseed.

\subsection{Climate scenarios for the years 2005-2050}

Projections for the most relevant climate variables under climate change scenarios are shown in Table 2 . There was a clear

Table 2 Relationship between years from 2005 to 2050 and climatic variables experienced by crops from sowing to harvest: temperatures (average, maximum and minimum, degrees Celsius), solar radiation increase in temperature from 2005 to 2050 . The increase in minimum temperature was higher $\left(0.051\right.$ to $0.067{ }^{\circ} \mathrm{C}$ year $\left.{ }^{-1}\right)$ than the increase in maximum temperature $(0.029$ to $0.044{ }^{\circ} \mathrm{C} \mathrm{year}^{-1}$ ) for the same period. This asymmetric change in maximum and minimum temperatures is well documented (Karl et al. 1991). The rise in temperature was predicted by all six climate projections and was very consistent. No such drastic consistent change was observed for the other climate variables. Half the climate projections (KNMI, UCLM, and SMHI) showed an increase in potential evapotranspiration. Solar radiation was predicted to decrease in one of the six climate projections (METNO). Only one climate model simulated a significant increasing trend in rainfall (KNMI with an increase of $3.5 \mathrm{~mm}$ year $^{-1}$ ). The inconsistency in rainfall projections we found is not specific to North Cameroon Province or to the set of regional climate change projections we chose for this study but is a common feature of climate change scenarios in West Africa. Indeed, there is little

(watts per square meter), cumulated rainfall (millimeter), and potential evapotranspiration (millimeter)

\begin{tabular}{llllrlrl} 
Name of models & Average temperature & Maximum temperature & Minimum temperature & Solar radiation & Rainfall & Potential evapotranspiration \\
\hline KNMI & $0.052 * * *$ & $0.034 * * *$ & $0.067 * * *$ & $-0.01 \mathrm{NS}$ & $3.50 * * *$ & $1.31 * * *$ \\
DMI & $0.054 * * *$ & $0.032 * * *$ & $0.062 * * *$ & $0.00 \mathrm{NS}$ & $-0.50 \mathrm{NS}$ & $-0.42 \mathrm{NS}$ \\
GKSS & $0.054 * * *$ & $0.044 * * *$ & $0.065 * * *$ & $0.01 \mathrm{NS}$ & $-0.67 \mathrm{NS}$ & $0.42 \mathrm{NS}$ \\
METNO & $0.040 * * *$ & $0.029 * * *$ & $0.051 * * *$ & $-0.03 * * *$ & $-2.31 \mathrm{NS}$ & $-0.24 \mathrm{NS}$ \\
SMHI & $0.052 * * *$ & $0.044 * * *$ & $0.059 * * *$ & $-0.01 \mathrm{NS}$ & $-1.91 \mathrm{NS}$ & $1.12 * *$ \\
UCLM & $0.051 * * *$ & $0.038 * * *$ & $0.064 * * *$ & $-0.01 \mathrm{NS}$ & $1.01 \mathrm{NS}$ & $0.89 *$ \\
\hline
\end{tabular}

Regression coefficient followed by student's test results

$N S$ not significant

${ }^{*} p<0.05,{ }^{* *} p<0.01, * * * p<0.001$ by ANCOVA 
consensus regarding possible changes in monsoon rainfall in a warmer climate: some studies predict wetter conditions and some predict more frequent droughts (Druyan 2011). To our knowledge, only two recent studies (Biasutti and Sobel 2009; Patricola and Cook 2010) found a robust agreement across the various climate models of the IPCC CMIP3 ensemble in the seasonal distribution of Sahel rainfall (with a drier early season and positive rainfall anomaly at the end of the season) in contrast with a large uncertainty for summertime rainfall totals. The KNMI regional simulation predicted the most drastic changes in climate with an increase in annual rainfall and cumulated evapotranspiration and a decrease in solar radiation. Such changes are not driven by the large scale of the global climate model (ECHAM5 in this case) but by the use of the regional climate model. The same lateral boundary conditions as in the ECHAM5 climate model were used for the GKSS and DMI regional projections but no trend was revealed for rainfall, evapotranspiration, or for solar radiation.

\subsection{Projection of cotton growth under climate change scenarios}

A selection of output variables was analyzed and compared to reveal any trends in the responses to climate projections, changes in $\mathrm{CO}_{2}$, and different management across the sites. These output variables included crop phenology, water and $\mathrm{N}$ availability, aerial biomass, harvest indexes, and cottonseed yields. There was a clear reduction in the length of the cotton growth cycle with a reduction in both time from emergence to maturity and time from emergence to flowering (Table 3). These trends were significant at the $1 \%$ confidence interval. Every 10 years, there was a 1.23-day advance in the flowering date and a 2.2-day advance in maturity. This phenomenon was caused by the rise in temperature that accelerated the phenology in the model. The temperature-driven shortening of the crop cycle was confirmed in field trials conducted in glasshouses (Reddy et al. 1997). This shortening of the crop cycle is broadly consistent with findings based on process-based models (Jones and Thornton 2003; Berg et al. 2012) and on empirical relationships between crops and climate (Schlenker and Lobell 2010). Although a negative impact on crop yield and aerial biomass can be expected from shortening of the crop cycle, no clear changes in harvest indexes were predicted in our cotton simulations and the crop model even simulated an increase in aerial biomass and cottonseed yield (Table 3 ). The $\mathrm{CO}_{2}$ fertilizing effect appeared to counterbalance the presumably negative effect of the shortening of the grain filling period in the model. Indeed, the positive trend in crop yield disappeared when the simulation was run with a stable concentration of $\mathrm{CO}_{2}$ (380 ppm). Similar studies conducted in Cameroon on five different crops showed an increase in yield for $\mathrm{C}_{3}$ species (groundnut and soybean) and a minor decrease or no change for $\mathrm{C}_{4}$ species like maize, sorghum, and bambara nut (Tingem et al. 2008). The same contrasting results between the response of $\mathrm{C}_{3}$ and $\mathrm{C}_{4}$ species to climate changes have been widely reported (Roudier et al. 2011) and while the impact of climate change on crop yield is essentially negative for $\mathrm{C}_{4}$ crops whose photosynthesis does not appear to be directly stimulated by elevated $\mathrm{CO}_{2}$ (Ghannoum et al. 2000; Leakey 2009), future yield scenarios accounting for this effect are more optimistic for $\mathrm{C}_{3}$ crops. However, the $\mathrm{CO}_{2}$ effect is difficult to estimate accurately and to parameterize in crop models (Tubiello et al. 2007; Ainsworth et al. 2008), and
Table 3 Relationship (ANCOVA) between years and output variables: emergence date (Julian days), emergence to flowering (day), emergence to crop maturity (day), aerial biomass (kilogram per hectare), and cottonseed yields (kilogram per hectare) simulated by CROPGRO from 2005 to 2050

\begin{tabular}{lrrc}
\hline Name of variable & Mean & $\begin{array}{c}\text { Regression } \\
\text { coefficient }\end{array}$ & Student's test result \\
\hline Emergence date & 177 & & Not significant \\
Emergence to flowering & 58 & -0.10 & $<0.0001$ \\
Emergence to maturity & 106 & -0.17 & $<0.0001$ \\
Aerial biomass & 3,576 & 2.69 & 0.03 \\
Harvest index & 0.42 & & Not significant \\
Cottonseed yield & 1,487 & 1.30 & 0.01 \\
Cottonseed yield if CO 2 was stable & 1,453 & & Not significant \\
Cottonseed yield in tillage system & 1,469 & 0.048 & $<0.0001$ \\
Cottonseed yield in conservation agriculture system & 1,727 & 0.168 & $<0.0001$ \\
Cottonseed yield in no-tillage system & 1,381 & & Not significant \\
Cottonseed yield with KNMI runs & 1,697 & & Not significant \\
Cottonseed yield with DMI runs & 1,587 & & Not significant \\
Cottonseed yield with GKSS runs & 1,697 & & Not significant \\
Cottonseed yield with METNO runs & 1,343 & 2.57 & 0.049 \\
Cottonseed yield with SMHI runs & 1,415 & 2.48 & 0.03 \\
Cottonseed yield with UCLM runs & 1,392 & & Not significant \\
\hline
\end{tabular}


Leakey (2009) in his recent review considered that a $\mathrm{CO}_{2}{ }^{-}$ induced yield increase in current projections of future crop yields is probably overly optimistic. Local studies with free air carbon enrichment and cooperation between agronomists and modelers are needed to assess the crucial issue of the effect of climate change on the productivity of African crops.

The average increase in cottonseed yield of $1.3 \mathrm{~kg} \mathrm{ha}^{-1} \mathrm{year}^{-1}$ masks differences between the runs with the six global climatic models. The runs with METNO and SMHI were significantly correlated with years and produced respectively 2.57 and $2.48 \mathrm{~kg} \mathrm{ha}^{-1}$ year $^{-1}$ but the other four runs predicted no significant increase in cottonseed yields (Table 3). No significant trends in climatic variables (Table 2) explain this discrepancy. However, we can hypothesize that METNO combines two negative trends, a significant reduction in solar radiation of $-0.03 \mathrm{~W} \mathrm{~m}^{-2}$ year $^{-1}$ and a non-significant reduction in rainfall of $2.31 \mathrm{~mm} \mathrm{year}^{-1}$ and SMHI combines a non-significant reduction in rainfall of $1.91 \mathrm{~mm}$ year $^{-1}$ and a significant increase in potential evapotranspiration of $1.12 \mathrm{~mm}_{\text {year }}{ }^{-1}$.

The positive trend in crop yield also differed among the cropping systems (Table 3). On one hand, the slope of the regression between years and yields was not significantly correlated for no-tillage system, meaning that no positive trend could be expected for this system. On the other hand, the slopes for the tillage system and conservation agriculture were significantly correlated. Moreover, the positive slope was greater for the conservation agriculture system. This is likely due to the reduction in soil evaporation thanks to the mulch cover, as potential evapotranspiration is expected to increase (Table 2). Figure 3 suggests that the main driver of cotton productivity in our simulations was not climate changes but $\mathrm{N}$ uptake, which explained around $68 \%$ of variations in crop yield. When cumulated rainfall was beyond the optimum value (near $700 \mathrm{~mm}$ per crop cycle in Fig. 3a), there was a negative correlation between cumulated rainfall and crop yield. This negative correlation can be explained by the effect of excessive rainfall, which increases $\mathrm{N}$ leaching (Fig. 3d) and hence reduces $\mathrm{N}$ uptake (Fig. 3c). However, no direct measurement of $\mathrm{N}$ leaching has confirmed this assumption and the soil organic carbon model (CERES-Godwin) we used may overestimate $\mathrm{N}$ mineralization. Further parameterization of $\mathrm{N}$ dynamics would be necessary to draw a firmer conclusion. Moreover, if the main driver of cotton yield is $\mathrm{N}$ uptake, uncertainty concerning future yields would remain, as projections of rainfall (see results section), which can reduce $\mathrm{N}$ uptake by increasing $\mathrm{N}$ leaching, are not in agreement in our regional climate scenarios.
Fig. 3 Main drivers of cottonseed yields simulated by CROPGRO. Rainfall (a), cumulative evapotranspiration (b), Nitrogen uptake (c), and leaching (d) under six global climatic models, 45 years, three cropping systems, and two locations in North Cameroun simulated by Cropgro. Regression equations were a $(y=$ $-0.43 x+1,844, R^{2}=0.09$ ) note the sharper decrease in yield after $700 \mathrm{~mm}, \mathbf{c}(y=15.84 x+$ $\left.188, R^{2}=0.6779\right), \mathbf{d}(y=-10.2 x$ $+1,844, R^{2}=0.3089$ )
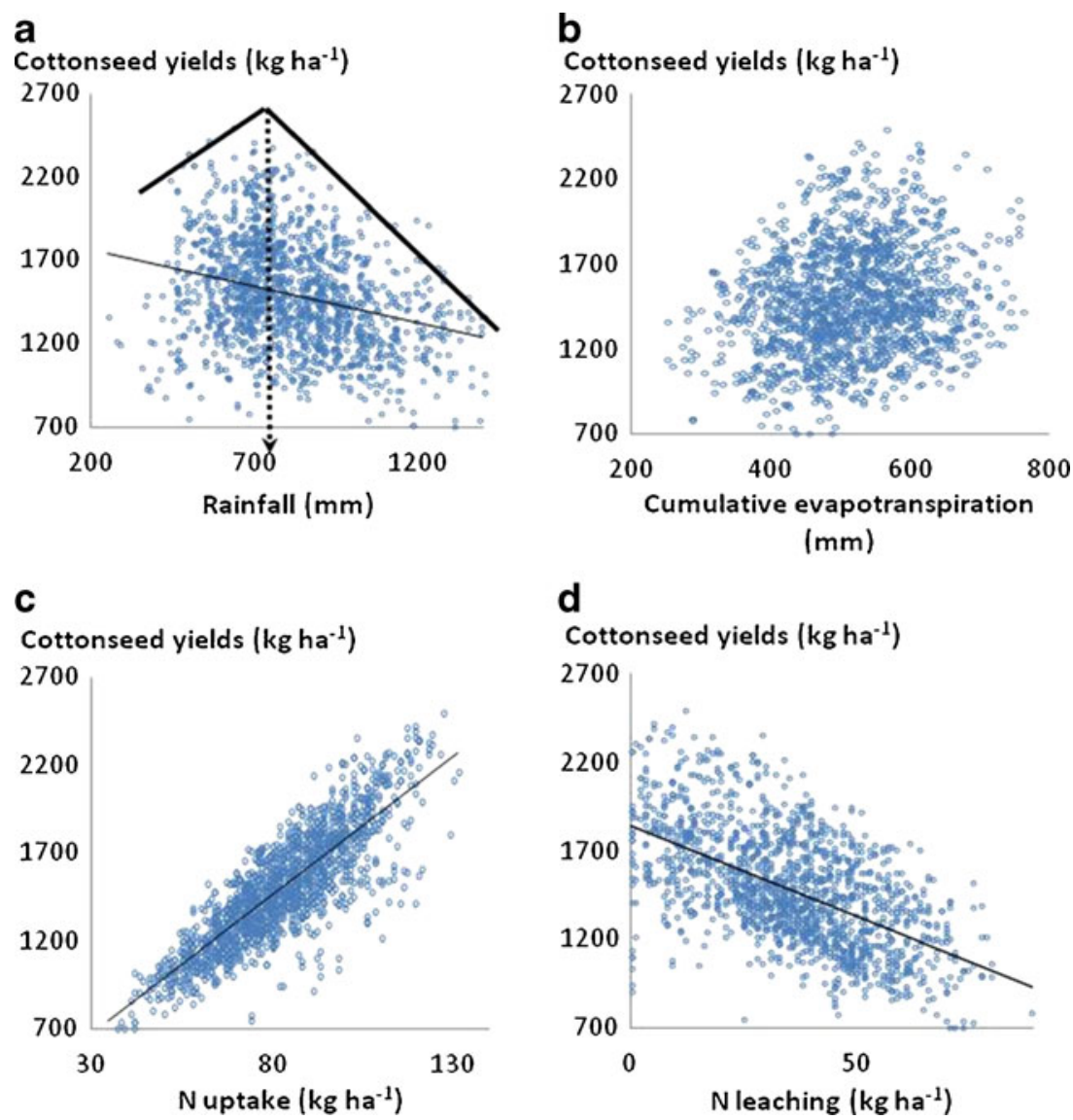

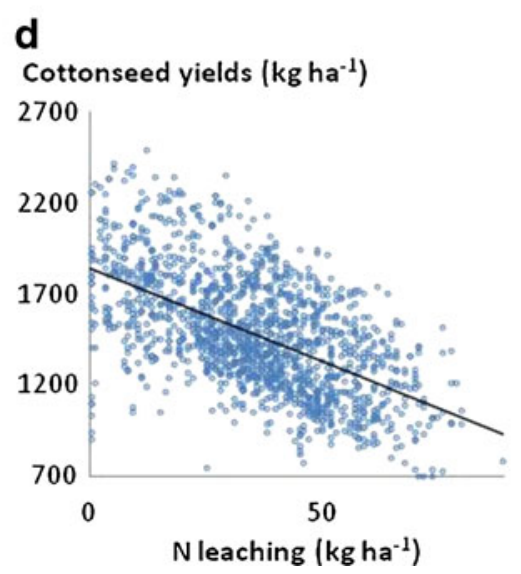




\section{Conclusion}

Our aim was to shed light on the trends of the yields of different cotton cropping systems in North Cameroon under a large range of climate change projections. Climate change will likely modify cotton growth conditions in North Cameroon. Our simulations showed an acceleration of the phenological cycle caused by the rise in temperature, while crop yields are expected to slightly increase between 2005 and 2050 because of the fertilizing role of $\mathrm{CO}_{2}$. However, the projection of future climate differs depending on the model used, especially for rainfall and potential evapotranspiration. The present paper quantifies the uncertainties in the projected yields depending on the climate models, but not depending on the choice of crop modeling. Another important result of our simulations is that climate change will affect the same crop under different cropping systems differently. We found that crop yield will increase under tillage and conservation agriculture systems while it is expected to remain unchanged under the no-tillage system. This result highlights the importance of the choice of the cropping system to cope with climate change effects.

It should be noted that our analysis focused on yield responses. Rural exodus or changes in crops may result in shifts in production regions with major impacts for producers but not necessarily for consumers. Another important caveat is that our analysis did not account for possible technological progress in coming decades. The rise in temperature will reduce the length of the cotton cycle expressed in days. Flowering and maturity will occur earlier if the same genotypes continue to be used. Given these changes, two options need to be considered to tailor crop management:

In the first option, a delay of 5 to 10 days in the planting date will be necessary if the genetic material used still has the same phenology. This is likely if genetic selection is unable to profoundly modify cotton genotypes. If this option is the one chosen, the cropping system will need to manage weeds and soil nitrogen between the start of the rainy season and the emergence of the crop.

The second option would be to modify the phenology of future cultivars by extending the beginning of flowering and extending the period of grain filling, which would delay crop maturity. Simulations on other crops in Cameroon have showed substantial increases in yield when cultivar parameters were adjusted to delay crop maturity (Tingem et al. 2009). The later flowering starts, the greater the amount of vegetative biomass that can later be converted into reproductive organs. Bolls in distal positions which normally do not reach maturity due to their late appearance could, in the future, have enough time to fill and thus increase the cotton yield.

Land use in cotton-producing area is mostly 8 years of cotton/cereal rotations and 6-10 years of natural fallow.
There is no doubt that climate changes will modify soil carbon dynamics as well as fallow regeneration capacity. Testing the effect of climate changes on the capacity of conservation agriculture to maintain soil fertility would be a complementary study. It would require sequential analysis of both crop rotations and fallows and would also need to assess the issue of grazing cattle.

Acknowledgments This study is a contribution to the PICREVAT project, funded by the French "Agence Nationale de la Recherche" under its VMCS 2008 program. The authors thank Philippe Letourmy for his assistance in statistics.

\section{References}

Ainsworth E, Leakey A, Ort D, Long S (2008) FACE-ing the facts: inconsistencies and interdependence among field, chamber and modeling studies of elevated $\left[\mathrm{CO}_{2}\right]$ impacts on crop yield and food supply. New Phytol 179:5-9. doi:10.1111/j.14698137.2008.02500.x

Berg A, de Noblet-Ducoudré N, Sultan B, Lengaigne M, Guimberteau $M$ (2012) Projections of climate change impacts on potential $C_{4}$ crop productivity over tropical regions. Agric For Meteorol. doi:10.1016/j.agrformet.2011.12.003

Biasutti M, Sobel AH (2009) Delayed Sahel rainfall and global seasonal cycle in a warmer climate. Geophys Res Lett. doi:10.1029/ 2009GL041303, Vol. 36, L23707, 5 pages

Blanc E, Quirion P, Strobl E (2008) The climatic determinants of cotton yields: evidence from a plot in West Africa. Agric For Meteorol 148:1093-1100. doi:10.1016/j.agrformet.2008.02.005

Druyan LM (2011) Studies of 21st-century precipitation trends over West Africa. Int J Climatol 31:1415-1424

Ghannoum O, Caemmerer SV, Ziska LH, Conroy JP (2000) The growth response of $\mathrm{C}_{4}$ plants to rising atmospheric $\mathrm{CO}_{2}$ partial pressure: a reassessment. Plant Cell Environ 23:931-942

He J, Jones JW, Graham WD, Dukes MD (2010) Influence of likelihood function choice for estimating crop model parameters using the generalized likelihood uncertainty estimation method. Agric Syst 103:256-264

IPCC (2007) Climate change 2007: working group I: the physical basis. Cambridge University Press, Cambridge

Jones PG, Thornton PK (2003) The potential impacts of climate change on maize production in Africa and Latin America in 2055. Glob Environ Chang 13:51-59. doi:10.1016/s0959-3780(02)00090-0

Jones JW, Hoogenboom G, Porter CH, Boote KJ, Batchelor WD, Hunt LA, Wilkens PW, Singh U, Gijsman AJ, Ritchie JT (2003) The DSSAT cropping system model. Eur J Agron 18:235-265

Karl TR, Kukla G, Razuvayev VN, Changery MJ, Quayle RG, Heim RR Jr, Easterling DR, Fu CB (1991) Global warming: evidence for asymmetric diurnal temperature change. Geophys Res Lett 18:2253-2256

Leakey ADB (2009) Rising atmospheric carbon dioxide concentration and the future of $\mathrm{C}_{4}$ crops for food and fuel. Proc R Soc B Biol Sci 276:2333-2343. doi:10.1098/rspb.2008.1517

Mbétid-Bessane E, Havard M, Djondang K (2006) Evolution des pratiques de gestion dans les exploitations agricoles familiales des savanes cotonnières d'Afrique centrale. Cah Agric 15:555-561

McGarry D (2006) A methodology of visual-soil field assessment tool to tupport, enhance, and contribute to the LADA program. FAO, Paris 
Michelangeli PA, Vrac M, Loukos H (2009) Probabilistic downscaling approaches: application to wind cumulative distribution functions. Geophys Res Lett 36:L11708. doi:10.1029/2009g1038401

Nakicenovic N, Alcamo J, Davis G, de Vries B, Fenhann J, Gaffin S, Gregory K, Grubler A, Jung TY, Kram T, La Rovere EL, Michaelis L, Mori S, Morita T, Pepper W, Pitcher HM, Price L, Riahi K, Roehrl A, Rogner H-H, Sankovski A, Schlesinger M, Shukla P, Smith SJ, Swart R, van Rooijen S, Victor N, Dadi Z (2000) Special report on emissions scenarios: a special report of working group III. IPCC, Geneva

Naudin K, Gozé E, Balarabe O, Giller KE, Scopel E (2010) Impact of no tillage and mulching practices on cotton production in North Cameroon: a multi-locational on-farm assessment. Soil Tillage Res 108:68-76

Patricola C, Cook K (2010) Northern African climate at the end of the twenty-first century: an integrated application of regional and global climate models. Clim Dyn 35:193-212. doi:10.1007/ s00382-009-0623-7

Reddy KR, Hodges HF, McKinion JM (1997) A comparison of scenarios for the effect of global climate change on cotton growth and yield. Funct Plant Biol 24:707-713. doi:10.1071/PP96138

Roudier P, Sultan B, Quirion P, Berg A (2011) The impact of future climate change on West African crop yields: what does the recent literature say? Global Environ Chang 21:1073-1083

Schlenker W, Lobell DB (2010) Robust negative impacts of climate change on African agriculture. Environ Res Lett 5:014010

Scopel E, Silva FAMD, Corbeels M, Affholder F, Maraux F (2004) Modelling crop residue mulching effects on water use and production of maize under semi-arid and humid tropical conditions. Agronomie 24:383-395
Soutou G, Naudin K, Scopel E (2007) Effet du semis sous couvert végétal sur l'infiltration, le ruissellement et simulation du bilan hydrique dans les systèmes de culture à base de coton au Nord Cameroun. In: Terre Malgache (ed) Les sols tropicaux en semis-direct sous couvertures végétales. Antananarivo, p 177-179

Steiner JL (1989) Tillage and surface residue effects on evaporation from soils. Soil Sci Soc Am J 53:911-916

Sultan B, Bella-Medjo M, Berg A, Quirion P, Janicot S (2010) Multiscales and multi-sites analyses of the role of rainfall in cotton yields in West Africa. Int J Climatol 30:58-71. doi:10.1002/joc. 1872

Tingem M, Rivington M, Bellocchi G, Azam-Ali S, Colls J (2008) Effects of climate change on crop production in Cameroon. Clim Res 36:65-77

Tingem M, Rivington M, Bellocchi G (2009) Adaptation assessments for crop production in response to climate change in Cameroon. Agron Sustain Dev 29:247-256. doi:10.1051/ agro:2008053

Tubiello FN, Amthor JS, Boote KJ, Donatelli M, Easterling W, Fischer G, Gifford RM, Howden M, Reilly J, Rosenzweig C (2007) Crop response to elevated $\mathrm{CO}_{2}$ and world food supply: a comment on "Food for Thought..." by Long et al., Science 312:1918-1921, 2006. Eur J Agron 26:215-223

Turner JH, Ramey HH, Worley S (1975) Influence of environment on seed quality of four cotton cultivars. Crop Sci 16:07-409. doi:10.2135/cropsci1976.0011183X001600030023x

van der Linden P, Mitchell JFB (2009) Ensembles-based predictions of climate changes and their impacts (ENSEMBLES): summary of research from the ENSEMBLE project. Met Office Hadley Centre, Exeter 